\title{
Integrative cases for teaching evolution
}

\author{
Peter JT White ${ }^{1 *}$, Merle Heidemann ${ }^{2}$, Miles Loh ${ }^{3}$ and James J Smith ${ }^{1}$
}

\begin{abstract}
Current university-level evolution instruction often suffers from a disjointed curriculum that separates molecular and ecological processes, at times omitting the former altogether. At the same time, national reform efforts call for the principles of evolution to be taught across the curriculum. We met this challenge by developing four cases (Mouse Fur Color, Pea Taste, Monkey Opsins and Clam Toxin) that present an integrated, comprehensive approach to teaching evolution across biological sub-disciplines. Our intent was to provide materials that post-secondary instructors could use to bolster their content knowledge and adapt for their students as they endeavor to configure their teaching to meet Vision and Change challenges. The material in any given case can be used to support the teaching of evolution across the curriculum, whether within a single introductory or advanced course, or more comprehensively across several courses. The cases are presented in a way that will allow instructors to quickly see how to apply this approach.
\end{abstract}

Keywords: Evolution, Evolution education, Integrative science, Science education, Case studies

\section{Background}

The problem: how can we help students understand evolution across biological scales?

As professional biologists, we know that the ability to integrate information and concepts across scales is critical for a working understanding of our broad discipline. At the same time, post-secondary instructors are often frustrated that their students can not integrate knowledge across different scales. For example, one of us (MH) routinely asks senior level undergraduate students what they know about proteins, across scales ranging from the molecular to the macroscopic. At a macro scale, the students mention meat, eggs and other foods known to be good sources of protein for their own well-being, while on the molecular level, students generally are able to provide the molecular details of transcription and translation. They also say that proteins are important for the function of an organism. However, these same students can actually name very few proteins and have an even foggier notion of how any protein functions. Perhaps more importantly, during this exercise, the students make no connections at all of proteins to any processes occurring at a cell biology level. There is a huge gap in

\footnotetext{
* Correspondence: pwhite@msu.edu

'Lyman Briggs College, Michigan State University, 919 E. Shaw Lane,

Rm. 36-E, East Lansing, MI 48825, USA

Full list of author information is available at the end of the article
}

their understanding of gene expression and the role(s) of proteins in building and maintaining cells and organisms. It follows that connections of cell functions to evolution, considered by students to be related to ecology but not cells, are not considered.

Related to this is the fact that biologists of all subdisciplines consider evolutionary theory to be foundational to their work. This holds true for molecular and cell biologists as well as ecologists. Experts realize that an understanding of evolution requires knowledge at all scales, from the molecular function of genes and proteins in a cell to how an organism is impacted by its environment. Thus, the inability to integrate concepts and information across scales is particularly problematic when students are learning how evolutionary processes work.

Unfortunately, most post-secondary instruction and standard biology curricula do not help students make connections across scales, especially with respect to evolutionary processes, as documented by Nehm et al. (2009). Their content analysis of three commonly used college biology textbooks showed "segregation of evolutionary information" throughout. For example, a perusal of standard introductory biology textbooks shows thorough and engaging examples of how alternate genotypes result in novel phenotypes (e.g., differences in Mendel's "T" and " $\mathrm{t}$ " alleles for height in pea plants). It is rarely made clear how

\section{实 Springer}


these examples of genetic variation might play out in some evolutionary process. In addition, the "Evolution" chapters in introductory biology textbooks are often focused on macroevolutionary processes and do not connect these processes to sections in the textbook where related molecular and cell biological concepts are presented. The widely used introductory biology textbook by Campbell et al. (2011, 9th Ed.) ends its presentation of a set of chapters on genetics with a section on recent genomics studies and how they relate, primarily in terms of genes that guide developmental processes, to genome evolution. Yet, the following chapter launches the student into a traditional "organismic" treatment of evolution with no connections made to either the prior chapter on genome evolution or the entire set of previous chapters on genetics. Thus, students miss an excellent opportunity to see how genome evolution connects to organismal evolution. This problem is compounded by the current practice of disassembling introductory biology textbooks into "relevant" chapters for courses. Introductory biology students at Michigan State University in fall semester 2012 purchased customized modular texts, consisting of selected chapters from the larger complete textbook (Campbell et al. 2011). One such modular textbook had chapters on biologically important molecules, cellular structure and function, and genetics; there was no reference to evolutionary processes.

Most treatments and presentations of evolutionary principles that our students experience also tend to be somewhat limited or superficial, leaving most of the cellular and molecular processes that contribute to evolution unexplained. Often this occurs when we teach the principles of evolutionary theory in an introductory organismal course before our students have gained any meaningful understanding of cellular and/or molecular biology. However, regardless of course sequence (organismal first, or cell and molecular first), introductory courses for majors and non-majors alike tend to focus the learning of evolution on variation and selection at a conceptual level. For example, students may be introduced to beach mice in the genus Peromyscus that have light coats as a result of natural selection against mice with dark coats on white sand beaches (Vignieri et al. 2010). However, typically little or no discussion will follow (or even be introduced) of the genes, proteins and cell biology that contribute to dark coats (Moore 2008, Smith et al. 2009). Thus, students tend to think of evolution as being relevant only to the macroscopic world, with little or no connection to what happens inside cells.

\section{A disjointed curriculum and its consequences}

This situation reflects the compartmentalized and disjointed nature of the typical undergraduate biology curriculum (Table 1). Students studying biology are generally introduced implicitly to biology as two separate "tracks": a cell and molecular biology track, and an organismal biology track, which includes discussions related to evolution. This dichotomy continues into upper level courses. Table 1 shows the typical "molecular" knowledge attained by students of biology, with an increasing sophistication of their understanding of "genes to proteins" as they progress through the curriculum.

Generally, standard undergraduate genetics courses begin with a Mendelian (genes/alleles/genotype/phenotype) approach, and students rarely connect these concepts to a later discussion of molecular genetics, let alone how any of this connects to a selectable phenotype. On the other hand, Table 1 shows how biology students are introduced to evolution as a treatment separate from, in most cases, their discussion of genetics, with the exception of algorithms related to population genetics. In general, there are few cellular and molecular concepts integrated into these organismal topics. And certainly, it is not common practice to discuss cellular events in the standard teaching of evolution.

Table 1 Basic components, as related to evolution science, found in typical post-secondary biology curricula

\begin{tabular}{|c|c|}
\hline a. Typical post-secondary biochemistry/genetics curriculum & b. Typical post-secondary organismal biology curriculum \\
\hline Intro Cell and Molecular Biology & Intro Organismal Biology \\
\hline - DNA $\Rightarrow$ RNA $\Rightarrow$ Proteins & - Chromosomes $\Rightarrow$ Genes/alleles $\Rightarrow$ genotype: Punnett square \\
\hline Genetics & $\begin{array}{l}\text { - Chromosomes } \Rightarrow \text { Genes/alleles } \Rightarrow \text { phenotype: genes "for a trait" (these ideas } \\
\text { often are not connected) }\end{array}$ \\
\hline - More detailed discussion of DNA $\Rightarrow$ RNA $\Rightarrow$ Proteins & - biodiversity and ecology \\
\hline - Regulation of gene expression & - Separate treatment of variation and natural selection \\
\hline - Chromosomes $\Rightarrow$ Genes/alleles $\Rightarrow$ genotype: Punnett square & Ecology \\
\hline - Chromosomes $\Rightarrow$ Genes/alleles $\Rightarrow$ phenotype: genes "for a trait or traits" & - Population ecology \\
\hline Biochemistry & - Interrelationship of Organisms (competition, predator-prey, etc.) \\
\hline - Details of transcription, translation, etc. & Evolution \\
\hline - Protein structure and function & $\begin{array}{l}\text { - Ideally integrates concepts addressed in other courses: molecular genetics, } \\
\text { biochemistry, genotype, phenotype, variation and natural selection }\end{array}$ \\
\hline
\end{tabular}


Ideally, all students of biology would take an upper level evolution course that would help them integrate biological concepts from molecules to ecosystems as they apply to evolutionary processes. Unfortunately, this is not often the case. For example, for the 2011 to 2012 academic year, only 193 out of roughly 600 students (around 32\%) graduating with degrees in the biological sciences through the College of Natural Science at Michigan State University had taken the senior-level evolution course (ZOL 445). Problematic as well, as detailed and discussed by Nelson (2012), students often leave traditional evolution courses not "getting" evolution. In addition, evolutionary principles would ideally be explicitly reinforced in all upper division biology courses in the curriculum; however, this rarely occurs. Thus, despite the central position of evolution in biology Dobzhansky (1973), most of our biology students are not given chances to develop their biological thinking across scales, a synthesis that is critical for understanding biology generally and from an evolutionary perspective.

Thus, it should not be surprising to us that even our advanced students have an array of misconceptions about many aspects of evolutionary theory. Many of our students think that an organism's needs cause evolutionary changes to take place (e.g., birds evolved wings in order to fly), or that the use or disuse of a trait explains its appearance or disappearance, or that all individuals in a population develop new traits simultaneously. These misconceptions are easily revealed by properly constructed concept inventories (e.g., Anderson et al. 2002; Bishop and Anderson 1990; Nehm and Reilly 2007; Fisher and Williams 2011). In addition, while students may be aware of (but not conversant with) the fundamental ideas of variation and natural selection, they are generally not aware of the kinds of evidence and reasoning that support these ideas. An adequate understanding of evolutionary theory requires a strong working knowledge of biology at all structural levels, including biochemistry, molecular genetics and cell biology. Students coming into introductory and even higher-level courses, lack this knowledge.

\section{Main text}

\section{Integrated cases as a solution}

A fundamental underlying problem is a failure to incorporate principles of cell and molecular biology into an integrated evolution-focused biology curriculum. Students are not provided with information about mechanisms underlying evolutionary change. Lacking an understanding of mechanisms allows misconceptions and alternative "theories" to take hold. These situations lead to the following questions: How well can students grasp evolution if they do not have an understanding of what genes are, how genes are expressed and the function of proteins in specific cells? What kind of understanding of genotypephenotype relationships can a student develop if they do not really know what proteins are and their relationship to cell biology? How can we help students to learn about the underlying molecular events that shape the organisms that interact with the environment?

We addressed these questions by developing a set of cases for teaching evolution, designed so that students can be introduced to a foundational understanding of evolutionary processes on a molecular level in terms of genes, proteins and cell function. These concepts are then connected with evolutionary processes on a macroscale. Our expectation is that the use of integrated materials will lead to a better understanding of evolutionary processes when they are presented at the organismal, population genetics or ecological level.

Our work is aligned with Vision and Change guidelines and recommendations for modernizing biology teaching and learning across the college curriculum made by the National Science Foundation (NSF) and the American Association for the Advancement of Science (AAAS) in conjunction with biologists and science educators across the United States (Brewer and Smith 2011). Of five core concepts identified, evolution was the first described, where Vision and Change explicitly states that "Inheritance, change, and adaptation are recurring themes supported by evidence drawn from molecular genetics, developmental biology, biochemistry, zoology, agronomy, botany, systematics, ecology and paleontology [emphasis is ours]." In terms of providing good instruction, Vision and Change admonishes instructors to "integrate core concepts and competencies [evolution] throughout the curriculum", beginning at the introductory level and revisiting fundamental ideas as students progress through their curriculum.

While college instructors are beginning to take these recommendations to heart, many, particularly those teaching the introductory sequences, have neither the resources nor the time to develop a new approach to their curriculum. One of our goals was to empower willing instructors by providing a set of teaching/learning materials they could implement as they exist or adapt as needed. In our experience at a large R1 institution, instructors need and want ready access to relevant examples and data when asked to teach outside their own areas of research expertise. In response, our pedagogical materials provide a rich, comprehensive and integrated pedagogical approach, with information and artifacts for teaching a given system across biological levels bundled together as cases. By providing the "whole story", an ecologist, for instance, would have examples of related genetic, molecular and cellular processes that would connect to the natural history and ecology with which they may be more familiar. Certainly, the reverse might be true of a 
biochemist endeavoring to teach population genetics and ecological concepts at the introductory level.

\section{The four cases}

To date we have developed and piloted four cases (Table 2): fur color in beach mice; taste in domesticated peas; color vision in Old and New World monkeys; and toxin resistance in clams.

The cases primarily were designed as ready to use material for instructors of post-secondary biology courses. Each case includes a classroom presentation in a PowerPoint ${ }^{\circledR}$ format that includes key illustrations and data sets. Other materials are case descriptions on the website, games, simulations and so on. All of the materials can be freely downloaded from our Evolution Cases website (http://www.evo-ed.com). We have endeavored to build educational materials that provide a simple and accurate foundational understanding of evolution by integrating principles drawn from molecular genetics, cell biology, ecology, population genetics and phylogenetics.

We used the principles of backward design (McTighe and Thomas 2003) to determine the content of the cases and to integrate that content across levels. We took as our starting point what we knew about the difficulties students have learning evolution when known underlying mechanisms are not presented. Our major goal was to provide a more comprehensive and integrated view of evolution. We also were guided by the lack of a coherent "genes to proteins to selectable phenotype" understanding that we had observed in our senior-level students. From these observations, we determined that the cases should: 1) provide clear evidence and examples from the literature for a "genes to proteins to selectable phenotype" approach of teaching and learning; 2) provide a scaffold for Vision and Change teaching methodology; 3) be flexible to meet instructors' needs and teaching styles; and, 4) be

Table 2 Four cases developed to support the teaching of evolution across the biology curriculum

\begin{tabular}{|c|c|}
\hline a. Mouse Fur Color - evolution of light fur in beach mice & $\begin{array}{l}\text { b. Pea taste - evolution of the wrinkled pea from ancestral (wild type) } \\
\text { round pea shape }\end{array}$ \\
\hline $\begin{array}{l}\text { The beach mouse, Peromyscus polionotus, lives in the southeastern US. } \\
\text { The fur color of subspecies varies from dark to very light brown and is } \\
\text { correlated with the color of the sand on which they live. Activities } \\
\text { presented in this case show the relationships among depredation, } \\
\text { substrate color and fur color. Peromyscus fur color is closely associated } \\
\text { with the MC1R protein, which stimulates the synthesis of the pigment, } \\
\text { eumelanin. A single nucleotide mutation in the mclr gene results in a } \\
\text { different form of the protein which impacts fur color. The biosynthesis } \\
\text { of eumelanin in the melanocyte is graphically presented. Recent } \\
\text { studies have shown correlations between the mc1r alleles and the coat } \\
\text { color phenotypes in populations of beach mice. Data from the work } \\
\text { of Kaufman (1974) on owl hunting of mice in different backgrounds, } \\
\text { correlations of background "brightness" and fur color (Belk and Smith } \\
\text { 1996) and predation studies of Peromyscus (Vignieri et al. 2010) are }\end{array}$ & $\begin{array}{l}\text { Every college student has heard the story of Mendel's peas (Pisum sativum), } \\
\text { first domesticated (an example of artificial selection) 10,000 BCE. Historically, } \\
\text { this organism served as the introduction to basic transmission genetics in } \\
\text { both secondary and post-secondary biology classes. Modern evidence } \\
\text { shows that an insertion of } 800 \text { nucleotides in the gene for starch branching } \\
\text { enzyme (SBE1) renders that enzyme non-functional in the homozygous } \\
\text { recessive (rr) condition. The biochemical pathway in pea cells with both } \\
\text { functional and non-functional SBE1 proteins is shown. Because sugars are } \\
\text { not converted into complex starches, these peas (rr genotype) accumulate } \\
\text { sugars and are sweeter. Ancient peoples liked the sweeter phenotype, } \\
\text { applying intense selection, which led to fixation of the r allele in populations } \\
\text { of cultivated peas. This intense selection is the basis for the Selective Farmer } \\
\text { Game, where the player can see the results of selection (or not) on the } \\
\text { proportion of alleles }(R, r) \text { in a field of peas over time. }\end{array}$ \\
\hline
\end{tabular}

included in this case. These studies provided basic information for the development of a game, where light or dark mice live on either a light or dark background and are subjected to predation. A second, timed, game allows the player to find light mice in various background colors. Additional data on allele frequencies and distribution of fur color alleles (e.g., Hoekstra et al. 2006) are included in the case.

\section{c. Monkey opsins - evolution of trichromatic vision in Old World monkeys}

The adaptive advantages of both dichromatic and trichromatic monkeys are presented in this case, using experimental data and activities that illustrate their foraging behavior. The phylogenetic relationships, as well as biogeographical information, among di- and trichromatic monkeys are well known; thus, the approximate time of the development of trichromatic vision can be inferred. Most students are aware that $\mathrm{red} / \mathrm{green}$ color vision is sex-linked in primates; a thorough discussion of the molecular and transmission genetics of these traits is presented. The differences between the three types of primate genes underlying color perception and the resulting proteins are discussed. Gene duplication and historical nucleotide changes in the red/green opsins are considered, as well as the structure and function of opsin proteins and cone cells. This case includes data regarding food selection and pattern recognition in di- and trichromats (Smith et al. 2003; Caine and Mundy 2000; and Saito et al. 2005). These data were the inspiration for the development of two games: 1) finding colored cereal as a di- or trichromat in a field; and 2) pattern recognition as either a di- or trichromat in variously colored backgrounds.

\section{d. Clam toxin - evolution of toxin resistance in clams}

\begin{abstract}
Mya arenaria is a species of soft shell clams, native to the eastern North American coast, where dinoflagellate "blooms" kill coastal creatures. The agent of death is saxitoxin, a potent neurotoxin. This toxin binds to voltage-gated sodium channels, preventing the required flow of sodium ions across the membrane for conduction of nerve impulses. The cell biology module of this case has a complete discussion of the cell biology and biomechanics of propagation of the action potential and how that is altered in the presence of a neurotoxin. Paralysis is the typical response to saxitoxin. In soft shell clams, a single nucleotide substitution in the gene coding for these channel proteins prevents binding of saxitoxin, ensuring normal nerve conduction even if the toxin is present (Bricelj et al. 2005). This is good for the clam, but bad for its predators, who can be poisoned by saxitoxin accumulation in clams. Studies have shown (Connell et al. 2007) that resistant clams with the mutated sodium channel are found where dinoflagellate blooms are more likely to occur.
\end{abstract}


comprehensive in that they "cover" the curriculum, yet have clear foci.

When searching the primary literature for systems to meet our first criterion, we found that there was a much broader knowledge base in the molecular genetics of alternative alleles than there was of the function of the resulting proteins and their role(s) in the cell. We expect this will change as proteomics catches up with genomics. That said, the cases presented here successfully meet the Vision and Change challenge to include comprehensive information for teaching evolution in an integrative fashion.

The cases provide information, models and data across all levels of the biological sciences. Thus, in an introductory course, an evolution course, or at various points across an undergraduate curriculum, a single case, or multiple cases, could be used to illustrate biological principles as they are encountered. Each case is presented as a set of sub-topics, and we sought to avoid hierarchical representation of case components. Thus, each sub-topic in each case was envisioned as a stand-alone module, with appropriate connections and references made between and among them. The individual components, while designed to be used together to tell a complete story, are strong enough to support teaching in the sub-disciplines. In addition, the cases include interactive app-style simulations and games that can be used by students.

Thus, the Ecology module for each case includes information about selective agents in the environment. All four cases provide appropriate explanations of the basic Cell Biology linked to each of the genotypes and phenotypes discussed. In addition, the Mouse Fur Color (Table 2a) and Pea Taste (Table 2b) cases include details of the underlying biochemistry of the cellular function, both in the original and mutated form. The discussion of Population Genetics is particularly strong for the Mouse Fur Color case (Table 2a), primarily based on the work of Hopi Hoekstra's group (http://oeb.harvard.edu/ faculty/hoekstra). Also, the work of Connell et al. (2007) documents the distribution of genotypes of resistant and non-resistant soft shell clams along the East Coast (Table 2d). In the Pea Taste case (Table 2b), the fixation of an allele, whose gene product is of use to humans, is discussed. This case also has an extended discussion of Mendel to Molecules, capturing the classic Mendelian experiments and tying them to modern day molecular genetics. An historical aspect of evolution is presented when discussing the evolution of color vision in Old and New World monkeys. Thus, basic tenets of phylogenetics are well illustrated in the Monkey Opsin case (Table 2c).

\section{Discussion}

We strove to provide a set of teaching materials that had a clear trajectory, but could be used in multiple ways.
While our basic recommendation would be to use each module/case as written, we realize that instructors will use them in ways that fit their immediate needs and time constraints. Thus, some instructors may successfully use the cases more or less as written, while others may choose examples from them that fill out or complement tried and true examples and activities that they already use in their classes. For example, parts of each of the four cases have been used either within an introductory biology course or the senior-level evolution course at Michigan State University. We have been documenting instructors' use of the cases through interviews. These interviews show, as expected, that some instructors use these materials more or less as written and others use them piecemeal, usually as additional examples of topics they are teaching.

\section{Cases or case studies?}

Our cases have slightly different goals than do the popular case studies collected in the repository archived by SUNY Buffalo (National Center for Case Study Teaching in Science - NCCSTS 2012). They do not follow the "usual" structure of cases (e.g., Herreid 1994; Herreid 2006; Herreid et al. 2012; Rybarczyk et al. 2007), in the sense that they do not include an engaging introductory story, detailed teaching notes, suggested student assessments and ways to structure discussions around the cases. Rather, our cases were designed to be comprehensive sets of content-based artifacts that can be accessed and used according to instructors' needs and teaching style. The structure of the cases is aligned with providing relevant, research-based and integrated materials that match the tenets of Vision and Change, wherein evolution is the basis for teaching and learning biological principles. The cases are expected to support instructors as they endeavor to integrate core ideas across content areas. Each case includes information on ecology, molecular genetics, population genetics (or phylogeny) and cell biology (protein function).

Recently, NCCSTS surveyed users of their case studies (Herreid et al. 2012). While we have been careful in categorizing our materials as cases, rather than case studies, our materials share some of the attributes valued by instructors who use cases. First and foremost, valued cases (studies) are those that are the "right topic". This certainly fits in with the current need to have approachable and comprehensive materials for teaching evolution. Other shared attributes are that they are realistic, relevant, current, clearly written and allow for critical thinking. The cases as they stand could be adapted to be case studies in the manner of the NCCSTS. Our group is in the process of using some of our posted artifacts to generate a story, build extensive teaching and student guides, and formative assessments. We invite other 
faculty to consider using our materials to develop case studies that complement their teaching styles in their own classes.

\section{Conclusion}

\section{Challenges and next steps}

This task was not without its challenges as we sought systems with research-based data and material that also would appeal to post-secondary students. The development process took on a life of its own as we embraced developing interactive app-style simulations for use by both instructors and students in class or to be assigned as homework (see Mouse Fur Color, Primate Color Vision and Pea Taste cases). We will document the use of these materials as we consider further development of simulations to support the cases.

The work described here is similar in spirit to studies in which acceptance of evolution has been shown to be positively correlated with genetic literacy (Miller et al. 2006). One also can speculate that non-scientific "theories" for evolution based on creationist beliefs/intelligent design (e.g., Dagher and BouJaoude 1997; Ingram and Nelson 2006; Sinatra et al. 2003) are more appealing to students with incomplete knowledge of the science of evolution. Our expectation is that when students are able to see evolution as the unifying principle across scales and levels, they will have a more robust understanding, not just of evolution, but of the entirety of biology.

We do not consider the cases as finished products. Rather, they will be continually revised as we interview instructors and get feedback from on-line users. Most importantly, measured student achievement as instructors use the cases is of paramount importance. They will be "works in progress" as we collect and analyze these data. We would welcome suggestions for improving and augmenting these cases and suggestions for other cases where good multilevel (molecules to natural selection) information and data are available.

\footnotetext{
Abbreviations

AAAS: American Association for the Advancement of Science;

NCCSTS: National Center for Case Study Teaching in Science; NSF: National

Science Foundation; SBE1: Starch branching enzyme.
}

\section{Competing interest}

The authors declare that they have no competing interests.

\section{Authors' contribution}

PJTW, JJS and MKH participated in project design and research. PJTW designed and assembled the cases and designed the website, assisted by ML. PJTW, JJS and MKH contributed to paper authorship. All authors read and approved of the final manuscript.

\section{Acknowledgments}

Partial support for this work was provided by the National Science Foundation's Transforming Undergraduate Education in Science, Technology, Engineering and Mathematics (TUES) program under Award No. 1043876. Any opinions, findings, and conclusions or recommendations expressed in this material are those of the authors and do not necessarily reflect the views of the National Science Foundation. We wish to thank Dr. Craig E. Nelson from Indiana University (emeritus) for his suggestions and feedback as this work was developed.

\section{Author details}

'Lyman Briggs College, Michigan State University, 919 E. Shaw Lane, Rm. 36-E, East Lansing, Ml 48825, USA. ${ }^{2}$ Department of Geological Sciences, Center for Integrative Studies, Michigan State University, 354 Farm Lane, Rm. 118, East Lansing, MI 48824, USA. ${ }^{3}$ Center for Integrative Studies, Michigan State University, 354 Farm Lane, Rm. 118, East Lansing, MI 48825, USA.

Received: 21 January 2013 Accepted: 6 March 2013

Published: 26 April 2013

\section{References}

Anderson, DL, Fisher, KM, \& Norman, JG. (2002). Development and evaluation of the conceptual inventory of natural selection. Journal of Research in Science Teaching, 39(10), 952-978.

Belk, MC, \& Smith, MH. (1996). Pelage coloration in Oldfield mice (Peromyscus polionotus): antipredator adaptation? Journal of Mammalogy, 77(3), 882-890.

Bishop, B, \& Anderson, C. (1990). Student conceptions of natural selection and its role in evolution. Journal of Research in Science Teaching, 27(5), 415-427.

Brewer, CA, \& Smith, D. (2011). Vision and Change in undergraduate biology education: a call to action. (79 pp). Washington, DC: American Association for the Advancement of Science.

Bricelj, VM, Connell, L, Konoki, K, MacQuarrie, SP, Scheuer, T, Catterall, WA, et al. (2005). Sodium channel mutation leading to saxitoxin resistance in clams increases risk of PSP. Nature, 434(7034), 763-767.

Caine, NG, \& Mundy, NI. (2000). Demonstration of a foraging advantage for marmosets (Callithrix geoffroyi) dependent on food colour. Proc Roy Soc Lond B, 267(1442), 439-444.

Campbell, NA, Reece, JB, Urry, LA, Cain, ML, Wasserman, SA, Minorsky, PV, et al. (2011). Campbell Biology. San Francisco, CA: Pearson Benjamin Cummings.

Connell, LB, MacQuarrie, SP, Twarog, BM, Iszard, M, \& Bricelj, VM. (2007). Population differences in nerve resistance to paralytic shellfish toxins in softshell clam, Mya arenaria, associated with sodium channel mutations. Marine Biology, 150(6), 1227-1236.

Dagher, ZR, \& BouJaoude, S. (1997). Scientific views and religious beliefs of college students: the case of biological evolution. Journal of Research in Science Teaching, 34(5), 429-445.

Dobzhansky, T. (1973). Nothing in biology makes sense except in the light of evolution. The American Biology Teacher, 35(3), 125-129.

Fisher, KM, \& Williams, KS. (2011). Concept Inventories/Conceptual Assessments in Biology (CABS): An Annotated List. http://www.sci.sdsu.edu/CRMSE/files/ Concept_Inventories_in_Biology_20110325.pdf.

Hoekstra, HE, Hirschmann, RJ, Bundey, RA, Insel, PA, \& Crossland, JP. (2006). Adaptive beach mouse color pattern. Science, 313(5783), 101-104.

Herreid, CF. (1994). Case studies in science: a novel method in science education. Journal of College Science Teaching, 23(4), 221-229.

Herreid, CF. (2006). Start with a story: the case study method of teaching college science. Arlington, VA: NSTA Press.

Herreid, CF, Schiller, NA, Herreid, KF, \& Wright, C. (2012). Case study: my favorite case and what makes it so. Journal of College Science Teaching, 42(2), 70-75.

Ingram, EL, \& Nelson, CE. (2006). Relationship between achievement and students' acceptance of evolution or creation in an upper-level evolution course. Journal of Research in Science Teaching, 43(1), 7-24.

Kaufman, DW. (1974). Adaptive coloration in Peromyscus polionotus: experimental selection by owls. Journal of Mammalogy, 55(2), 271-283.

McTighe, J, \& Thomas, RS. (2003). Backward design for forward action. Educ Leader, $60(5), 52-55$.

Miller, JD, Scott, EC, \& Okamato, S. (2006). Public acceptance of evolution. Science, 313(5788), 765-766.

Moore, A. (2008). Science teaching must evolve. Nature, 453(7191), 31-32.

National Center for Case Study Teaching in Science - NCCSTS. (2012). http:// sciencecases.lib.buffalo.edu/.

Nehm, RH, \& Reilly, L. (2007). Biology majors' knowledge and misconceptions of natural selection. BioScience, 57(3), 263-272.

Nehm, RH, Poole, TM, Lyford, ME, Hoskins, SG, Carruth, L, Ewers, BE, et al. (2009). Does the segregation of evolution in biology textbooks and introductory 
courses reinforce students' faulty mental model of biology and evolution? Evol Educ Outreach, 2(3), 527-532.

Nelson, CE. (2012). Why don't undergraduates really "get" evolution? In K. S. Rosengren, E. M. Evans, S. Brem, \& G. Sinatra (Eds.), Evolution challenges: integrating research and practice in teaching and learning about evolution (pp. 311-347). Oxford, UK: Oxford University Press.

Rybarczyk, BJ, Baines, AT, McCey, M, Thompson, JT, \& Wilkins, H. (2007). A casebased approach increases student learning outcomes and comprehension of cellular respiration concepts. Biochemistry and Molecular Biology Education, 35(3), 181-186.

Saito, A, Mikami, A, Kawajura, S, Ueno, Y, Hiramatsu, C, Widayati, KA, et al. (2005). Advantage of dichromats over trichromats in discrimination of color-camouflaged stimuli in nonhuman primates. American Journal of Primatology, 67(4), 425-436.

Sinatra, GM, Southerland, SA, McConaughy, F, \& Demastes, JW. (2003). Intentions and beliefs in students' understanding and acceptance of biological evolution. Journal of Research in Science Teaching, 40(5), 510-518.

Smith, AC, Buchanan-Smith, HM, Surridge, AK, Osorio, D, \& Mundy, NI. (2003). The effect of colour vision status on the detection and selection of fruits by tamarins (Saguinus spp.). Journal of Experimental Biology, 206(Pt.18), 3159-3165.

Smith, JJ, Baum, DA, \& Moore, A. (2009). The need for molecular genetic perspectives in evolutionary education (and vice versa). Trends in Genetics, 25(10), 427-429.

Vignieri, SN, Larson, JG, \& Hoekstra, HE. (2010). The selective advantage of crypsis in mice. Evolution, 64(7), 2153-2158.

doi:10.1186/1936-6434-6-17

Cite this article as: White et al:: Integrative cases for teaching evolution. Evolution: Education and Outreach 2013 6:17.

\section{Submit your manuscript to a SpringerOpen ${ }^{\circ}$ journal and benefit from:}

- Convenient online submission

- Rigorous peer review

- Immediate publication on acceptance

- Open access: articles freely available online

- High visibility within the field

- Retaining the copyright to your article

Submit your next manuscript at $\gg$ springeropen.com 